Donata Ochmann

Uniwersytet Jagielloński, Kraków

donata.ochmann@uj.edu.pl

\title{
CZY FAJNY JEST FAJNY? WSPÓKCZESNE LEKSEMY MŁODZIEŻOWE O ZNACZENIU ‘TAKI, KTÓRY MI SIĘ (BARDZO) PODOBA’
}

Słowa klucze: leksyka młodzieżowa, slang, wyrazy modne Keywords: teenage vocabulary, slang, trendy words

1. Tytułowy przymiotnik fajny (z niem. fein m.in. 'w dobrym gatunku' USJP) to słowo wciąż krytykowane przez współczesnych normatywistów jako nadużywane i nieprecyzyjne czy też - ze względu na potoczność - jako stylistycznie niedopasowane do sytuacji mówienia (WSPP; Kołodziejek 2010: 52). Diagnozy te jednak dalekie są od negatywnych, często emocjonalnych ocen formułowanych, również przez niejęzykoznawców, w drugiej połowie XX w., a zwłaszcza w latach 70. i 80. ${ }^{1}$ Zostały one już w pewnym stopniu podsumowane (R. S. 1982; Urban 1990), dlatego dla oddania atmosfery tych wypowiedzi przytoczę jedynie skrajną opinię Danuty Wesołowskiej:

[...] dbając o czystość i piękno języka polskiego nie powinno się wyrazu fajny (fajnie, fajno) używać nawet w potocznej mowie; dyskwalifikuje go nie tylko jego obce pochodzenie,

1 Ciekawe, że brak uwag na ten temat we wcześniejszych syntezach normatywnych - słownikach poprawnej polszczyzny Stanisława Szobera (1963), Witolda Doroszewskiego i Haliny Kurkowskiej (1981), ale także w: Z zagadnień kultury języka Alojzego Adama Zdaniukiewicza (1973) czy Kulturze języka polskiego Danuty Buttler, Haliny Kurkowskiej, Haliny Satkiewicz $(1986,1987)$. 
ale przede wszystkim fakt, że jest jednym z owych wyrazów-wytrychów, które zubożają nasze współczesne słownictwo polskie („Dziennik Polski” 1979, 1980, za: Urban 1990: 57; zob. też Klemensiewicz 1962: 327; Siekierska 1969: 333; M.S. 1979; Miodek 1983: 45, 81, 142; Kochański, Klebanowska, Markowski 1989: 269-270).

Stopniowe łagodzenie krytyki wiązać można ze zmianą stosunku do zapożyczeń, zwłaszcza niemieckich po II wojnie światowej, postępującą potocyzacją polszczyzny i przemijalnością mody. W poradniku językowym z początku lat 9o. znajdujemy stanowisko zdystansowane - na temat modnych ekspresywizmów czytamy:

Można oczywiście ubolewać, że fajny (w dodatku barbaryzm), wdechowy, bombowy itp. panoszą się nad miarę - niemniej jednak jest to zjawisko w rozwoju języka naturalne i wyrazy takie mogą być traktowane z pewną tolerancją (Bąba, Walczak 1992: 12).

Mimo że obecnie słowo przestało już być postrzegane jako modne ${ }^{2}$, powszechność jego użycia może razić użytkowników polszczyzny wychowanych na jego krytyce.

Ciekawe, że mimo ogólnego występowania, odzwierciedlanego przez słowniki ${ }^{3}$, a także wskazywanego przez badaczy upowszechnienia w polszczyźnie potocznej za pośrednictwem gwar (M. S. 1979: 39) lub jidysz (R. S. 1982: 189), najsilniej kojarzone jest z językiem młodzieży. Wynika to prawdopodobnie z jego dawniejszej szczególnej popularności w tej grupie użytkowników, na co wskazują zarówno przywoływane wyżej wypowiedzi niektórych badaczy, jak i notacje w zbiorach słownictwa młodzieżowego (Czarnecka, Zgółkowa 1991; Kaczmarek, Skubalanka, Grabias 1974/1994 (jako pot.), z późniejszych również Czeszewski 2001 i Zgółkowa 2004). Przyczyną tego może też być automatyczne łączenie nieakceptowanego słowa $\mathrm{z}$ grupą posługującą się językiem w dużej mierze potocznym, uproszczonym, podatnym na mody, której zwyczaje językowe należy kształtować.

Refleksja metajęzykowa i działania dydaktyczne mające na celu choć częściowe wyeliminowanie słowa stanowią jednak z perspektywy funkcjonowania slangu czynnik mniej istotny. Ważniejsza jest charakterystyczna dla slangu stała dążność do odświeżania zasobu leksykalnego i silnego nacechowania ekspresywnego leksyki, która niejako wymusza zmienność. Równie ważna wydaje się tu popularność słowa w polszczyźnie potocznej - osłabia w pewnym stopniu jego slangową atrakcyjność, a w konsekwencji uruchamia procesy pomnażające liczebność określeń synonimicznych.

2 Por. np.: „...stare słowa modne są zastępowane przez nowe, tak jak było z szeregiem przymiotników ekspresywnych, o bardzo ogólnikowym znaczeniu: 'oceniany bardzo pozytywnie': klawy, wdechowy, fajny, git, super, ekstra, cool” (Markowski 2005: 211). Moment ten symbolicznie poświadcza też pominięcie przez Andrzeja Markowskiego felietonu nt. słów modnych Fajny kompleksowy problem z książki Polszczyzna znana i nieznana (1993) w drugim rozszerzonym jej wydaniu (1999).

3 Przypomnę, że notowane jest już w SW, a jako potoczne od SJPD we wszystkich słownikach współczesnego języka polskiego. 
Nie są to bynajmniej zjawiska nowe i nieobjęte dotychczas refleksją naukową. Artykuł niniejszy stanowi jednak próbę podsumowania obserwacji dotyczących grupy leksemów synonimicznych do przymiotnika fajny, o znaczeniu 'taki, który mi się (bardzo) podoba', notowanych w języku młodzieży początku XXI w. - ukazania ich zarówno na tle współczesnych przemian językowo-kulturowych (procesy strukturalne, zapożyczenia, potocyzacja, wulgaryzacja i dewulgaryzacja, zabawa słowem) oraz kategorii charakterystycznych dla slangu (ekspresywność, zmienność, moda, bogactwo), jak i w perspektywie leksykografii slangowej.

2. Głównym źródłem zgromadzonego materiału są współczesne słowniki dotyczące młodzieżowej odmiany języka, zarówno drukowane (Czeszewski 2001; Tkaczyk 2002; Dziurda, Choroba 2003; Zgółkowa 2004; Chaciński 2007; Jendrzejek, Pastwa 2006; Koślicka 2006; Fliciński, Wójtowicz 2007; Widawski 2010), jak i internetowe (Miejski słownik slangu i mowy potocznej, Vasisdas). Gromadzą one słowa identyfikowane jako młodzieżowe, co okazuje się istotne w czasie intensywnego przenikania tej leksyki do polszczyzny ogólnej potocznej. Słowniki stanowią źródło niezwykle bogate, choć często ze względu na popularną formę czy amatorskie autorstwo wymagają weryfikacji i uzupełnienia (por. np. niedostatki warsztatu leksykograficznego w słownikach elektronicznych, częste definicje synonimiczne czy brak materiału ilustracyjnego). Dlatego wykorzystano również inne dostępne źródła, w tym język mówiony, ankiety itp.

3. Materiał poddany oglądowi obejmuje okres kilkunastu ostatnich lat (na ile można to było ustalić na podstawie podawanych przez autorów informacji, zakres materiałowy ekscerpowanych słowników zamyka się w latach 1995-2013). Dla slangu jest to okres bardzo długi. Ze względu na wspomnianą zmienność i konkurencyjność wypierających się form ważna wydaje się więc ich chronologizacja. Niestety, dostępny materiał słownikowy nie zawsze może być podstawą do tego rodzaju wniosków. Nie wynika to wyłącznie z niepełnej dokumentacji materiałowej, ale raczej z natury omawianego przedmiotu, jego dynamiki i nieuchwytności, co skutkuje słownikową notacją leksemów zarówno współwystępujących, jak i (nie)odległych w czasie. Trzeba jednocześnie pamiętać, że młodzież nie stanowi grupy jednolitej, mamy raczej do czynienia $\mathrm{z}$ wielością (pod)grup młodzieżowych, zróżnicowanych ze względu na wiek i zainteresowania. W przypadku analizowanego tutaj pola leksykalno-semantycznego decydujący o różnicach może być również wyznawany system wartości.

Uwzględniając te ograniczenia, skupiam się tu na stanie współczesnym (z początku XXI w.), a uwagi chronologiczne, stylistyczne i semantyczne formułuję dość ogólnikowo. Przedmiotem dociekań nie będą więc naturalne dla slangu młodzieżowego, uwarunkowane czasowo i środowiskowo, różnice w nacechowaniu emocjonalnym czy stylistycznym między poszczególnymi jednostkami, ale sposoby bogacenia omawianego pola leksykalno-semantycznego. Zgromadzone leksemy omówione zostaną 
w obrębie kilku grup formalnych, ilustrujących pewne mechanizmy językowe, istotne z perspektywy systemu językowego, jego przemian zachodzących pod wpływem współczesnych zjawisk społeczno-kulturowych.

\section{a. fajowy, fajowski, fajoski}

Wielość derywatów słowotwórczych świadczy o dużej popularności, a zarazem o chęci odświeżenia wyjściowego przymiotnika, co nie jest zjawiskiem nowym: formę fajowy notuje już dawniejszy Słownik gwary uczniowskiej z 1991 r. Przywołując ją, Roxana Sinielnikoff (1982: 190) zwróciła uwagę na zmianę postrzegania budowy leksemu fajny przez młodych użytkowników języka: $f a j n-y>f a j-n y^{4}$. Obserwowane przekształcenie formalne można więc interpretować jako wymianę sufiksu (czy raczej sufiksoidu: $-n y$ : -owy), ale też jako wynik ucięcia i sufiksacji $(f a j[n y+-o w y)$. Za tą drugą interpretacją przemawia zwłaszcza popularność dezintegracji w tworzeniu neologizmów slangowych. W nowszych strukturach znamienne jest też utrwalenie postaci fonetycznej (fajoski). Eksperymenty formalne na płaszczyźnie ortograficznej są bowiem również jedną z cech charakterystycznych dla współczesnego slangu młodzieżowego (por. Przybylska 2009; Ochmann 2013).

Warto zwrócić $\mathrm{w}$ tym miejscu uwagę na procesy derywacyjne w slangu, przede wszystkim na różnorodność wykorzystywanych formantów i technik słowotwórczych, związaną czasem z trudnościami interpretacyjnymi, gdyż dotyczą one niemal wszystkich wyodrębnionych tu grup (zob. niżej).

\section{b. super, ekstra, mega; pro, spoko, wporzo, zaje}

Zgromadzone tu formy ilustrują jedne z najważniejszych zjawisk współczesnego polskiego słowotwórstwa. Pierwsze $\mathrm{z}$ wymienionych leksemów funkcjonują w polszczyźnie od dłuższego czasu, a ich popularność i strukturalna nowość zaowocowały osobnymi opracowaniami naukowymi (por. Przybylska 1995; Mycawka 2000). Podkreślano zwłaszcza związaną z ich funkcjonowaniem hiperbolizację i emocjonalizację przekazu oraz prawdopodobny wpływ strukturalny języka angielskiego. W tym miejscu warto zwrócić również uwagę na proces przekształcania się formalnych prefiksów czy określających członów związanych złożeń w samodzielne leksemy (zob. np. Ochmann 2004: 51).

W wyniku działania innego mechanizmu słowotwórczego powstały przymiotniki spoko (spoko[jny), zaje (zaje[bisty) i wporzo (choć w tym przypadku jest to nieco

4 Być może również dlatego współcześnie wydają się nietypowe formy notowane w SW: fajnisty, fajnowaty, fajnowny. W polszczyźnie potocznej funkcjonują też inne derywaty zawierające cały rdzeń: SPLP obok fajnisty notuje fajniacki, fajniuchny i fajniutki. Z nowszych można wymienić jeszcze fajniusi, fajnisi. 
bardziej skomplikowane: wym. wporzo[ndku $<$ w porządku) - dezintegracja podstawy jest zjawiskiem typowym dla slangu, a zarazem coraz częstszym w polszczyźnie ogólnej (por. formy info, porno, korpo itd.).

Ogólne podobieństwo formalne zestawionych tu podgrup (wyodrębnienie z większej całości, przeważnie dwusylabowość i wygłosowa samogłoska) może być źródłem charakterystycznej dla współczesnego słowotwórstwa strukturalnej analogii, wyznaczać miejsce ucięcia czy sposób interpretacji nowych jednostek, zwłaszcza przy zatarciu się stosunków motywacyjnych i zmianach semantycznych częstych w slangu. Ciekawą ilustracją tego zjawiska jest nowy przymiotnik pro („bo ty pro dziewczyna jesteś!"), notowany jedynie w uzupełnianym stale przez użytkowników internetowym Miejskim słowniku slangu m.in. z charakterystyczną definicją 'extra, super' („- uwaga, skacze z dachu - jesteś pro"). Inna zamieszczona tam definicja precyzuje: 'pro to beznadziejne określenie kogoś, kto jest super, fajny lub dobry w jakiejś grze’. Leksem wywodzony jest z języka graczy w gry komputerowe od słów profesjonalista, professional. Wprawdzie jego związek z prefiksem pro- (z łac. 'za, dla, na czyjąś korzyść'), interpretowanym współcześnie również jako związany człon złożeń o znaczeniu 'pozytywny, przychylny', semantycznie wydaje się możliwy, jednak nie ma powodu do podważania danych słownikowych.

Do całej serii można też dodać derywaty obrazujące omawianą wyżej dążność do odświeżenia leksyki z wykorzystaniem różnych środków słowotwórczych: superowy (super + -owy), superancki (super + -ancki) (funkcjonujące już wcześniej, Przybylska 1995; por. też superowskie - Czarnecka, Zgółkowa 1991), superaśny (super + -aśny), supcio (sup[er + -cio), ekstraśny (ekstra + -śny), spoczko (spok[o + -ko, k: č), spoks (spok[o + -s), spox (spo[ko + -x), spoksi (spok[o + -si), spokusi (spok[o + -usi), spoxi (spo[ko + -xi), sponio (spo[ko $+-n i o)^{5}$. Poza konkurencyjnymi sufiksami mamy tu do czynienia z dezintegracją oraz przekształceniami fonetyczno-ortograficznymi (formy spoks, spox, spoksi, spoxi można też interpretować jako warianty ortograficzne).

Zauważmy, że na poziomie semantycznym w powyższych przykładach ujawnia się rozpiętość między wspomnianą już intensyfikacją (super, mega) a zdystansowaniem (spoko, wporzo). Widać to również w formach zapożyczonych.

\section{c. cool, trendy, seksi, stit}

oraz: kul (ang. cool 'chłodny'), fresz (ang. fresh 'świeży'), jazzy, dżezi (ang. 'krzykliwy, ekscentryczny'), edgy, edżi (ang. 'drażliwy, prowokujący'), dżusi (ang. juicy 'soczysty'), fanki (ang. funky 'inny, ekscentryczny'), fleszi (ang. flashy 'błyszczący'); coolowy, sweetaśny, stitaśny (sweet 'słodki, miły'), lajtowy (light 'lekki'), debeściacki,

$5 \mathrm{~W}$ analizie ograniczam się do przymiotników, choć odpowiednie przysłówki zwykle funkcjonują równolegle, a niekiedy są to formy równokształtne, nie zawsze też rozdzielane czy w ogóle notowane (Miejski notuje też sup, supko, ale jedynie w kontekstach przysłówkowych). 
debeściarski (the best 'najlepszy'), maksiarski (maxi 'duży, największy'), okijkowy (ok, oki 'w porządku')

Dość oczywiste jest, że w omawianej tu kluczowej dla młodzieżowego slangu sferze leksyki oceniającej silnie rysuje się tendencja do przejmowania zapożyczeń z języka angielskiego i poddawania ich różnorodnym przekształceniom adaptacyjnym: fonetycznym, graficznym, słowotwórczym (por. np. kul, stit, dżezi, coolowy, stitaśny, debeściarski), niekiedy niestandardowym (okijkowy). Powszechny i codzienny kontakt $\mathrm{z}$ angielszczyzną niewątpliwie sprzyja takim działaniom. Zapewnia też możliwość sięgania do użyć slangowych, w których zapożyczane leksemy również funkcjonują jako synonimy służące do pozytywnego wartościowania zjawisk ${ }^{6}$. Mimo że grupa ta jest liczna, część jednostek ma stosunkowo krótki i ograniczony żywot, na co w felietonowym stylu zwraca uwagę Bartek Chaciński (2007: 86):

„Pojawia się pytanie: czy ta książka jest trendy?” - zapytał ktoś. „Teraz już nie trendy, tylko fresz. Trendy już nie jest fresz" - padła odpowiedź. A na to ktoś inny zareagował: „Nie fresz, tylko dżezi, fresz już nie jest dżezi”. Swobodnie można pociągnąć tę konwersację dalej. Otóż nie dżezi, bo dżezi już dawno nie jest edżi. Ale też nie edżi, bo edżi dawno już nie jest seksi. Z kolei seksi od jakiegoś czasu nie jest dżusi, więc może dżusi? Gdybyż dżusi było jeszcze fanki, ale nie jest! I nawet nie mam pewności, czy fanki wciąż jest fleszi, zatem może fleszi?

Z innych zapożyczeń warta odnotowania jest pewna trwałość czy raczej odnowienie funkcjonowania leksemu git z jidysz przez dawną gwarę złodziejską i grypserę; współczesne słowniki notują: gitowy, gitny, gites, gitesowy, gitasowy.

\section{d. odlotowy, odjazdowy, odjechany, czadowy, czaderski, bajerancki, wypasiony, wyczesany, totalny, gruby, tłusty, fazowy, bekowy, epicki}

Neosemantyzacja uchodzi za najważniejszy sposób wzbogacania slangowego słownictwa (Grabias 1997: 226). Nie dziwi więc, że do starszych form (czadowy, odjazdowy) w badanym polu dołączają nowe jednostki utworzone na tej zasadzie (totalny, gruby, epicki). Zgromadzone tu leksemy ilustrują różne typy charakterystycznych dla slangu młodzieżowego przekształceń semantycznych: zarówno zmiany promieniste (odlotowy, odjazdowy, odjechany; wypasiony, wyczesany, gruby, tłusty), jak i wspierane pożyczkami obcymi (epicki $i^{7}$ ), a także nakładanie się procesów strukturalnych i semantycznych (czadowy, czaderski - czad 'coś wspaniałego, niepowtarzalnego',

6 Por. np. cool, sexy, flashy, jazzy, fresh, edgy, funky (www.urbandictionary.com); fresh - cool, trendy; jazzy - flashy (www.merriam-webster.com).

7 W polszczyźnie za modnym amerykańskim neosemantyzmem epic 'wspaniały, wielki, mocny, spektakularny' (por. www.urbandictionary.com). 
fazowy - faza 'euforia', bekowy - beka 'coś śmiesznego'). Punktem inicjującym zmianę jest duża intensywność nazywanej cechy lub określanego zjawiska, co wiąże się ze wspominaną już hiperbolizacją i emocjonalizacją wypowiedzi slangowych, stałym dążeniem do odnawiania środków ekspresywnych.

Ważne z perspektywy omawianego zagadnienia wydają się zwłaszcza przesunięcia znaczeniowe w obrębie funkcjonujących w slangu słów, zacieranie się różnic semantycznych, mogące być konsekwencją ich wysokiej frekwencji, nadużywania związanego z modą, np. bajerancki, wypasiony to 'efektowny' (bajerancki telefon, wypasiony samochód) i 'świetny' (bajerancka, wypasiona piosenka), podobnie bekowy to 'śmieszny, zabawny, na luzie' (bekowy film, bekowa fryzura) i 'miły, fajny' („Nie będę wszystkiego opisywać [...] każdego wydarzenia, bo bez kitu same bekowe i pozytywne”, „Dawid kupił kartki dla kilku dziewczyn. Takie fajne... Bekowe" - Chaciński 2007: 23-24). Ujawniają się w ten sposób wartości akceptowane, pożądane w grupie młodzieży: efektowność, intensywność, zabawa, swoboda.

Ciekawym zjawiskiem jest nakładanie się różnych mechanizmów językowych, uruchamianie skojarzeń w planie formalnym i treściowym, czasem trudnych do zrekonstruowania. Przykładem może być ciąg zależnych leksemów naruszających tabu związane z seksualnością, używanych w interesującym nas znaczeniu 'świetny, fajny': genialny - genitalny - ideanalny. Można tu dostrzec przekształcenie semantyczne motywowane podobieństwem brzmieniowym (paronimia), pociągające za sobą zmianę łańcuchową (analogia) z pominięciem jednego członu (idealny), dającą w efekcie nową strukturę (kontaminacja). Podobnie aksamitny w omawianym tu znaczeniu można wiązać z ciągiem: jedwabisty < zajedwabisty < zajebisty.

\section{e. zajebisty}

oraz: zajebiaszczy, zajefajny, zajedwabisty, zajebiotyczny, zajekarpisty, zajewasaty, zajekurwabisty, zarabisty, zaglebisty, zagilbisty, zagrzybisty, zabajony, jedwabisty; wyjebany (w kosmos), wyjechany w kosmos, wyjefajny, wykurwisty, wyrabisty, wyrąbany (w kosmos), wybombisty, wyczepisty

Manifestacyjna wulgaryzacja zachowań językowych jest częstym zjawiskiem w okresie dorastania (Kowalikowa 2008: 86), dlatego sięganie po środki ekstremalne wpisane jest w charakter slangu młodzieżowego, o czym świadczy między innymi duża liczebność niniejszej grupy. Leksem zajebisty, a także jego przekształcenia zadżebisty, zadżebiasty w znaczeniu 'wspaniały, doskonały' notowane były w zbiorach słownictwa młodzieżowego już dawniej (Czarnecka, Zgółkowa 1991), współcześnie jednak jego popularność znacznie przekracza granice slangu, choć kojarzony jest właśnie z młodym pokoleniem (por. Zajebiści egoiści - zapowiedź artykułu o młodzieży na okładce „Newsweeka” 22/2013). W związku z jego funkcjonowaniem można zaobserwować dwie tendencje: 
1) proces dewulgaryzacji wynikający z olbrzymiej popularności słowa;

2) proces eufemizacji wynikający jedynie częściowo $\mathrm{z}$ chęci uniknięcia wulgarnego słowa, a w dużej mierze z przekornego aluzyjnego przywołania go w postaci form brzmieniowo podobnych (jedwabisty, zabajony) lub strukturalnie przekształconych, analogicznych, kontaminacji itp.: zarabisty (wymiana rdzenia: -jeb- : -rąb-), zajebiaszczy, zajebiotyczny (zmiana sufiksu: -isty: -aszczy: -otyczny), zajefajny (zaje[bisty + fajny), zajedwabisty (zajebisty + jedwabisty), zajewasaty (zaje[bis]ty + wąsaty), zajekarpisty (zaje[b]isty + karp), zagrzybisty (za[je] bisty + grzy $)$ ), zaglebisty $(z a[j] \underline{e b i s t y}+\operatorname{Gleb}(a)-$ pseudonim $)$.

Dotyczy to również innych wymienionych tu wulgaryzmów: wyjebany (wyraba$n y$, wyjechany, wyjefajny: wyje[ba] $\underline{n y}+$ fajny), wykurwisty (wyrabisty, wybombisty, wyczepisty).

Zabawa słowem, aluzyjność są przejawem wspomnianej już tendencji ogólnej do uzyskania atrakcyjności formalnej wypowiedzi. W konsekwencji żart zaciera tutaj poczucie wulgarności, niestosowności słowa, przesuwa granicę jego społecznej akceptowalności.

Wulgaryzacja polszczyzny ogólnej, wiązana między innymi z jej potocyzacją, ma niewątpliwie również źródło we współczesnym postrzeganiu młodości jako wartości oraz w przejmowaniu postaw i zachowań charakterystycznych dla młodzieży (tzw. moda na luz). Przekraczanie konwencji środowiskowej i czasowej tłumaczącej pewne zachowania językowe odczuwane jest jako rażące, nieakceptowalne, stąd negatywna ocena modnego słowa ${ }^{8}$, przywodząca na myśl dawniejszą krytykę wyrazu fajny. Symptomatyczne dla skali zmian kulturowych są różne przyczyny braku ich akceptacji: dawniej obcość (ściślej: niemieckość), dziś - wulgarność.

\section{f. zacny, godny}

Słowa te nie są nowe, ale wyodrębniają się spośród omówionych wyżej neosemantyzmów nawiązaniem do stylu wysokiego. Interesujące nas notacje znajdziemy jedynie w Miejskim, dlatego warto je zacytować w całości:

godny 'fajny, interesujący': Patrz, jaka godna dziara!

8 Z wywiadu z Walerym Pisarkiem: „Czy »zajebiście« to brzydkie słowo? - Na mój smak bardzo, bardzo brzydkie! Kulturalną polszczyznę obłażą od czasu do czasu takie wszy; ani się od nich uwolnić, ani je zignorować. Jeżeli już musimy ich używać (a przyznaję, że czasem naprawdę musimy), to nie róbmy tego publicznie i głośno. Mnie też się czasem zdarza zakląć, i to tak grubo, że sam jestem zaskoczony. Pozwalam sobie jednak na to tylko w samotności albo w towarzystwie przyjaciół rówieśników. Jako należący do starszego pokolenia pan od polskiego nie mogę patrzeć przez palce na ordynarne zachowania językowe moich ziomków na ulicy, w tramwaju, w szkole, na uniwersytecie, w Sejmie i w mediach, więc będę bronił kulturalnej polszczyzny przed słowem "zajebiście«. - Upewnię się tylko: »zajebiście» od "jebać«? - Z całą pewnością tak" (krakow.gazeta.pl 12 IV 2013; por. też liczne wypowiedzi Jana Miodka). 
Pod hasłem godnie: 'mianem „godnym” określamy rzecz/sytuację/osobę, która nam się podoba i jest interesująca':

- Widzisz tą blondynkę? To z nią się umówiłem.

- Tą po prawej? Oo godna jest;)

- Kupiłam sobie nową sukienkę, jak Ci się podoba?

- Godna!

zacny (pod hasłem zacnie) 'coś fajnego, coś, co Cię fascynuje i ci się podoba!':

- co myślisz o jego nowej płycie?

- Zacna, Zacna :D

A także:

zacny w chuj 'warty zwrócenia uwagi, oglądnięcia':

- No i jak Ci się film podoba?

- Zacny w chuj.

Przytoczone konteksty świadczą, że mamy tu do czynienia z odświeżaniem słów podniosłych, książkowych i odczuwanych jako dawne (por. też plebs, szlachta). Wprawdzie Stanisław Grabias (1997: 238) wspomina o obecności tego typu leksyki w języku młodzieży (głównie nazw osób), ale najczęściej w funkcji ironicznej, czego tutaj nie obserwujemy. Na tle omówionych wyżej zjawisk w pewnym stopniu typowych dla współczesnej polszczyzny (procesy słowotwórcze, zapożyczenia, wulgaryzacja) to wydaje się znaczącą innowacją.

4. W powyższym zestawieniu dostrzec można dwie główne tendencje:

1) oscylacja między rosnącą grupą anglicyzmów a niezwykle licznymi neosemantyzmami wraz z odświeżaniem zasobu leksyki wysokiej, książkowej;

2) stała aktywność procesów słowotwórczych - choć różnych typów: od struktur typowych, regularnych (fajowy, fajnisty, spoko, zaje), przez coraz bardziej jednostkowe zabawy strukturalne (spokusi), po będące nośnikiem aluzji, gry językowe (ideanalny, zajedwabisty). Sama kategoria zabawy jako wartości może być różnie oceniana, nie ulega jednak wątpliwości, że zabawa językowa wymaga inteligencji i świadomości metajęzykowej.

To, co wydaje się jednak najważniejsze, to przede wszystkim bogactwo nowych form, którego nie można wiązać wyłącznie z dostępnością materiału współczesnego, choć sytuacja ta z pewnością ułatwia badania. Wydaje się, że kategorie zmienności i mody zwykle przywoływane dla objaśnienia tego typu sytuacji w slangu wymagają jednak uzupełnienia, podkreślenia niezwykłej kreatywności użytkowników, traktowania tworzywa językowego z pewną lekkością, wręcz dezynwolturą, zabawy formą, co uwidaczniać się może zwłaszcza podczas badań ankietowych, które umożliwiają notację 
indywidualizmów, okazjonalizmów, form potencjalnych (np. gite, kozak, mró, pupcio, superekstra, superere; Jelonek 2012: 78).

Podważanie na tej podstawie tezy o języku młodzieży jako kodzie ograniczonym (dysponującym niewielkim arsenałem środków) byłoby jednak zbyt pochopne, ponieważ - jak już wspominano - współwystępowanie owych słów może nie być pełne zarówno chronologicznie, jak i socjologicznie (krótkotrwałe mody i wielość (pod)grup młodzieżowych).

Argumentów pomocnych w zweryfikowaniu tezy o obserwowanej bierności umysłowej, ubóstwie znaczeniowym określeń, dominacji wyrazów-wytrychów mogłaby dostarczyć odpowiedź na pytanie, czy bogactwu leksemów i ich różnorodności formalnej towarzyszy zróżnicowanie semantyczne i stylistyczne. Być może krótkie trwanie blokuje zacieranie się wyrazistości znaczeniowej (por. wyjściowo bekowy 'śmieszny', lajtowy 'lekki, na luzie', stitaśny 'miły', zajebisty 'doskonały, bardzo intensywny')? Te aspekty nie były tu przedmiotem dociekań, ale z pewnością stanowią ciekawe pole obserwacji. Materiał słownikowy, zwłaszcza ilustracyjny, musiałby być jednak uzupełniony analizą tekstów.

Na zakończenie należy również zadać pytanie: czy omawiane konkurencyjne formy wyrugowały z użycia przymiotnik fajny? Mimo ich stałego przenikania do polszczyzny ogólnej (potocznej) - co wiąże się z obserwowaną przez badaczy potocyzacją współczesnej polszczyzny, ze swoistą nobilitacją tej odmiany języka, objawiającą się np. częstym sięganiem do jej charakterystycznej leksyki - na pewno nie. Ewa Kołodziejek pisze:

Pozycji przymiotnika fajny nie zagrozi ani super, ani cool, ani inne modne nowości, ponieważ używają go wszyscy, bez względu na wykształcenie i stosunek do języka (Kołodziejek 2010: 52).

Dotyczy to również młodzieży. Mimo że nie notują go nowsze zbiory leksyki młodzieżowej i wbrew obiegowym opiniom o wyparciu go przez inne słowa (por. np. Miodek 2007: $65^{9}$ ) ankietowe badania pokazują, że fajny wciąż wymieniany jest przez młodych ludzi w grupie określeń zjawisk akceptowanych. Tomasz Jelonek (2012: 211-212) notuje m.in.: fajna babka, fajna dupa, fajna dziewczyna, fajna laska, fajna muza, fajna nuta, fajna nutka, fajna zabawa, fajne ciacho, fajny chłopak, fajny facet, fajny kawałek, fajny koleś, fajny singiel, fajny song, fajny towar. Potwierdzają to również inne prace licencjackie poświęcone leksyce gimnazjalistów, pisane pod moim kierunkiem, a także sondaż przeprowadzony przeze mnie wśród studentów na potrzeby tego tekstu ${ }^{10}$. Odpowiadając na tytułowe pytanie, w konwencji stylistycznej użytkowników omawianej leksyki można by zatem powiedzieć, że fajny wprawdzie nie jest zajefajny, ale na pewno pozostaje fajny.

9 „Ale fajna babka! - to typowa wypowiedź moich rówieśników i ludzi starszych ode mnie - reakcja na widok ładnej dziewczyny, kobiety. Dzisiaj laska jest super, ekstra, mega i cool".

10 Badanie zostało przeprowadzone w listopadzie $2012 \mathrm{r}$. na grupie 60 studentów polonistyki UJ i miało na celu sprawdzenie, jakimi słowami określają oni akceptowane przez siebie zjawisko (udana 


\section{Literatura}

BĄвa S., Walczak B., 1992, Na końcu języka. Poradnik leksykalno-gramatyczny, Warszawa - Poznań.

Buttler H., Kurkowska H., Satkiewicz H., 1986, Kultura języka polskiego. Zagadnienia poprawności gramatycznej, Warszawa.

Buttler H., Kurkowska H., SAtKiewicz H., 1987, Kultura języka polskiego. Zagadnienia poprawności leksykalnej, Warszawa.

CHACIŃsKi B., 2007, Totalny słownik najmłodszej polszczyzny, Kraków.

Czarnecka K., ZgóŁkowa H., 1991, Słownik gwary uczniowskiej, Poznań.

Czeszewski M., 2001, Słownik slangu młodzieżowego, Piła.

Doroszewski W., Kurkowska H. (red.), 1981, Słownik poprawnej polszczyzny PWN, Warszawa.

Dziurda M., Сноroba P., 2003, Słownik gwary młodzieżowej, Toruń.

Fliciński P., Wójtowicz S., 2007, Hip-hop słownik, Warszawa.

GRABIAS S., 1997, Język w zachowaniach społecznych, Lublin.

JelONEK T., 2012, Na melanżu czadowa nutka - leksyka gimnazjalistów z początku XXI wieku, Kraków.

Jendrzejek A., Pastwa J., 2006, Słownik gwary młodzieżowej, Toruń.

Kaczmarek L., Skubalanka T., Grabias S., 1974/1994, Słownik gwary studenckiej, Lublin. Klemensiewicz Z., 1962, Pisarskie słownictwo Marii Dąbrowskiej, „Język Polski” z. 5, s. 321-330.

Kochański W., Klebanowska B., Markowski A., 1989, O dobrej i złej polszczyźnie, Warszawa.

KoŁodziejek E., 2010, Walczymy z bykami. Poradnik językowy PWN, Warszawa.

KośLICKa K., 2006, Słownik hip-hopu, Toruń.

Kowalikowa J., 2008, O wulgaryzacji i dewulgaryzacji we współczesnej polszczyźnie, „Język a Kultura” t. 20: A. Dąbrowska (red.), Tom jubileuszowy, Wrocław, s. 81-88.

Markowski A., 1993, ${ }^{2}$ 1999, Polszczyzna znana i nieznana. Porady. Ciekawostki. Dyktanda konkursowe, Warszawa.

Markowski A., 2005, Kultura języka polskiego. Teoria. Zagadnienia leksykalne, Warszawa.

MiejSKr: Miejski słownik slangu i mowy potocznej, www.miejski.pl.

Miodek J., 1983, Rzecz o języku. Szkice o współczesnej polszczyźnie, Wrocław.

Miodek J., 2007, Słowo jest w człowieku. Poradnik językowy, Wrocław.

M. S.: [M. Szymczak], 1979, Czy powinniśmy używać przymiotnika fajny?, „Poradnik Językowy” Z. 1, s. 38-39.

Mycawka M., 200o, Derywaty z mega- we współczesnej polszczyźnie, „Język Polski” z. 1-2, S. $15-22$.

Ochmann D., 2004, Nowe wyrazy złożone o podstawie zdezintegrowanej w języku polskim, Kraków.

Ochmann D., 2013, Słowotwórstwo najmłodszej polszczyzny, [w:] E. Badyda, J. Maćkiewicz, E. Rogowska-Cybulska (red.), Wokół słów i znaczeń V: Słowotwórstwo w różnych odmianach języka. Materiały piątej konferencji językoznawczej poświęconej pamięci profesora Bogusława Krei, Gdańsk, s. 153-164.

Przybylska R., 1995, Super, „Język Polski” z. 2, s. 104-107.

impreza). Warto przy okazji zwrócić uwagę, że określeniu fajny towarzyszą słowa silnie nacechowane ( fajna dupa), poza tym fajna jest raczej książka, a impreza - zajebista. 
PrZybylska R., 2009, O niektórych anglicyzmach w języku młodzieży, [w:] A. Janus-Sitarz (red.), W trosce o dobra edukację. Prace dedykowane profesor Jadwidze Kowalikowej z okazji 40-lecia pracy naukowej, Kraków, s. 102-112.

R. S.: [R. Sinielnikoff], 1982, Stuletnia wojna o przymiotnik fajny, „Poradnik Językowy” z. 3, S. $189-193$.

SieKIERSKa K., 1969, Słownictwo pamiętników młodzieży wiejskiej, „Poradnik Językowy” z. 6, S. $330-335$.

SJPD: W. Doroszewski (red.), Słownik języka polskiego, Warszawa 1958-1969.

SPLP: W. Lubaś (red.), Słownik polskich leksemów potocznych, t. II: D-F, Kraków 2003.

Szober S., 1963, Słownik poprawnej polszczyzny, wydanie czwarte uzupełnione, Warszawa.

SW: J. Karłowicz, A.A. Kryński, W. Niedźwiedzki (red.), Słownik języka polskiego, Warszawa $1900-1927$.

TкасZук A., 2002, Słowniczek gwary uczniowskiej, Wrocław.

URBAN K., 1990, Społeczna waloryzacja kolokwializmów, „Socjolingwistyka” IX, s. 47-69.

USJP: S. Dubisz (red.), Uniwersalny słownik języka polskiego PWN, Warszawa 2003.

VAsISDAS, www.vasisdas.pl.

WidAwski M. (red. nauk.), 2010, Slang UG. Słownik slangu studentów Uniwersytetu Gdańskiego, Gdańsk.

WSPP: A. Markowski (red.), Wielki słownik poprawnej polszczyzny PWN, Warszawa 2004.

ZDANiUKieWiCZ A.A., 1973, Z zagadnień kultury języka, Warszawa.

ZGóŁKowA H. (red.), 2004, Nowy słownik gwary uczniowskiej, Wrocław.

\section{Is fajny 'cool' cool? Modern teenage lexemes meaning 'such that I like (a lot)' Summary}

The paper examines the functioning of a very numerous group of lexemes synonymous to the adjective fajny 'such that I like (a lot)', which can be found in the language of contemporary teenagers, e.g. fajowy, super, spoko, cool, stit (sweet), odjazdowy, wypasiony, epicki, zajebisty, zacny. It analyses the conditions and methods used to multiply this category of lexemes in the teenage slang - which has these days a powerful impact on general Polish. The points of reference are the phenomena characteristic of slang: expressiveness, fashion, richness of synonyms and tautonyms. These questions are considered against the background of current cultural and linguistic changes (structural processes, borrowing, colloquialization, vulgarization and devulgarization, word play). 